\title{
Early Childhood Education Policy: A Qualitative Research based on the Implementation of Strategies During the Civil War in Myanmar
}

\author{
1,2 Mai Jacinta, OP * \\ ${ }^{1}$ University of Santo Tomas, Graduate School, Manila, Philippines \\ ${ }^{2}$ Dominican School of Calabanga, Camarines Sur, Philippines
}

\begin{abstract}
Every child has the right to study. It is the responsibility of society to create the opportunity to learn. Early Childhood Education develops a child's social, emotional, cognitive, and physical needs, shaping a firm foundation of wellbeing and lifelong learning. This study assesses in early childhood education how the new strategies and approaches are implemented during the current civil war in Myanmar. The sample size was 20 teachers selected from 5 regions (three regions freed war zone and two regions from the war zone). Questionaries, interviews, and observation were used as research instruction. The study finds out that the challenges that the educators encounter, the implementation of new strategies that respond to the needs of the student, and the effect of the approaches that continue to progress the development of early childhood despite the chaos and tragedies caused by the civil war.
\end{abstract}

Keywords: Early Childhood Education; implementation of methods; teaching strategies

\section{Introduction}

UNICEF has issued that no child is left behind that all children have the right to go to school and learn, regardless of who they are, where they live, or how much money their family has. In human development, early childhood is the most critical because the experiences that the children encounter during this stage of life have a long-lasting impact on individual health, academic success, wellbeing, and social adjustment (Franks et al., 2017). Early Childhood Education is the 
period of learning from birth to eight years old. Since it is the time of building cognitive, physical, and emotion, it is a period of intense, rapid growth and development. Therefore, ECE is the contributor to the child's capacity (Cherrie, 2018). Early childhood education develops the physical and mental aspects of the child and the spiritual aspect of the child. In 2020, the Queensland Department of Education stated that ECE policy aims to guide and achieve the intended goal for children's development. The policy informs parents, teachers, and caregivers how the services operate.

\section{Background of Myanmar during the civil war}

According to Heiduk (2021), starting from February 1, 2021, in Myanmar, the military junta took over the government, claiming that the 2020 election was fraudulent. They detained all the top political officials, including State Counselor Aung San Suu Kyi and President Win Myint, following the announcement of the state's emergency for one year. The sudden hit of authority caused the civil war between the military and newly formed government called the National Unity Government (NUG), which stands for the people's rights. The civil war creates tragedies and costs the lives of the people in Myanmar. People have to leave their homes and move to the jungle to be safe from the harm of bullets, bombs, and weapons.

Due to the civil war, no schools were opened. Many children have been living in the forest together with their family where there is no school and no facilities for study. On the other hand, children living in the free war region are not attending school as well because most of the teachers were involved in the Civil Disobedience Movement, and at the same time, parents decided not to send their children to schools which are opened under the military junta. It is a way of expressing their rejection of the military. However, children growing day by day need to underpin for their growth, especially during the civil war, which affects their emotional, mental and physical. This paper will find out how teachers try to reach out in a way they could in order to fulfill the needs of children despise of the challenges of the civil war. 


\section{Myanmar Early Childhood Education Policy}

Early Childhood education is the education of children that builds cognitive, physical, and emotional development (Cherrie, 2017). Early Childhood education is crucial for each individual, and it establishes the foundation of development. It is the stage that the child learns how to communicate and explore the environment. ECD is the foundation of the learning among the students where a child progress skills and abilities effectively (Kapur, 2018).

According to Myat (2014), Myanmar considers children from the time birth to 8 years old across the country to be fundamental for human resource development and play a vital role for the developed and democratized Nation. It implements the ECE policy to ensure that the children in Myanmar receive services to obtain full potential in development. The implementation of the activities and strategies are not just quantity but the quality of the services. The government of the Republic of Myanmar issued Myanmar Early Childhood Education Policy in 2014 with the purpose that every child in Myanmar will receive services to achieve their full potential and development. Myanmar policy for ECE presents a major national initiative for the child. The government of Myanmar gives high priority to children's education with the following strategies:

1. Services for children, 0 to 3 years- It is the plan for the parents of children from 0 to 3 years to receive integrated parent education through home visits and center-based services. It is to ensure that all children and parents access regular preventive and basic health, nutrition, environmental sanitation, and protection services. Comprehensive parent education support services are provided to improve their skill in nurturing and raising children, which involve training of manuals and utilizing education material on many topics such as maternal, newborn child health and nutrition, child development sequences, etc.

2. Preschool education for children, 3 to 4 years- This policy strategy is to improve the development of the children 3 to 4 years to ensure parent participation in their children education in order to prepare and obtain success learning environment in kindergarten and primary grades, 5 to 8 years. To attain high-quality preschool education culturally and linguistically, a child-centered methodology is utilized in which facility of individual, small and large group activity including learning through play and learning corner in the 
classroom. Parent involvement in preschool is essential, and continued parents' education focuses on health care, good nutrition and child hygiene, safety, and security of children 3 to 4 years of age.

3. Transition, Kindergarten and early primary grades, $\mathbf{5}$ and $\mathbf{8}$ years- This strategy is to develop a strong transition program for children from 4 to 5 years of age from preschool to kindergarten and primary school. It has child-centered approaches with active learning methodologies for early grade teaching, learning through play, and leaning corners because children learn best through active involvement. It includes parent participation in the schools, use of the mother tongue for learning basic concepts.

\section{Objectives}

-to assess the challenges and obstacles of teaching during the civil war

-to identify different approaches of teachers to be able to teach during the civil war focusing on ECE

-to assess the learners' output in response to the different strategies that are implemented by teachers to cope with the situation caused by civil war

\section{Research Questions}

1. How do you reach out to the children in order to help them?

2. What hinders your teaching during the civil war?

3. Knowing that children need you in this time of crisis, how do you implement strategies that will meet the need of children?

4. How does your teaching strategies help children during the civil war?

\section{Research Methodology}

To demonstrate the implementation of approaches in Early Childhood Education during the civil war, qualitative research will be utilized through group discussions, interviews, and surveys. By observing the social distances, which is required by COVID-19 protocols and due to the 
continual civil war in Myanmar, the method will be conducted online. Messenger and zoom application for interviews and group discussion, google form for the survey, and other related pieces of literature. Participants are selected from five regions: 3 regions from the freed war zoneMandalay, Magway, Sagaing; 2regions from the war zone- Karen and Kachin.
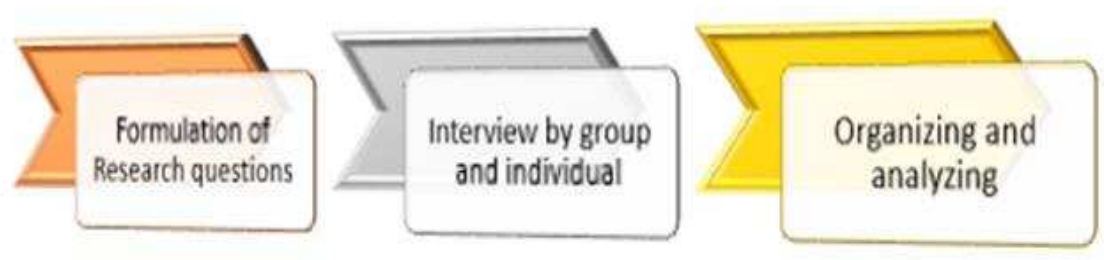

\section{Research Methods}

\section{Finding}

Myanmar education was delayed due to the spread of the COVID-19 disease, and it was completely destroyed after the military junta staged a coup. It caused severe damage to parents, students, and teachers. However, students who are precious for the country's future have to pay attention to their education, especially the children. To continue their education, teachers try to integrate interim education in their place and in their own time. The purpose of the study was to discover the challenges, the strategies or approaches that the educators use, and the effect of the approaches during the civil war. The following are obtained:

\section{Challenges of Teachers during the civil war}

Civil war conveys injury, diseases, dislocation, misery, and death. Moreover, it affects the varieties of human aspects, and education is one of the affected aspects (Gersovitz \& Kriger, 2013). This challenges educators to continue their teaching and form the future of children. In this context, a teacher stated, 
"Because of war, it is not safe for children to go to school. The lessons planned for the whole year are not taught as well as they should be. The school was closed. So, there is no place to facilitate students."

A teacher also claimed,

"Even though we are teaching in our space and time, parents and teachers are under threat due to the report of the people who stand in the side of the military. It pressures us, and we have to look at the convenient situation from time to time."

A teacher remarked,

"We offered online classes, but due to the moving from place to place to avoid the guns and bullets, it is difficult to build a teaching and learning environment. Inconvenience in living hinders as well."

It was well explained by the respondents regarding their challenges in teaching during the civil war. The absence of a secure place where they could freely conduct the lesson and the atmosphere of uncertainty to both teachers and students are the major challenges in education. In a moment that life is at risk, no matter how the teachers are well prepared in their lesson and even though they have the necessary materials for teaching, if the environment is not safe, everything will be at stake. It can be seen that the challenges that teachers encounter are hindering in educating the students, especially the little ones who need assistance to learn. In early childhood education, providing a safe and creative atmosphere is essential for children to learn through the sense. However, teachers understand that teaching is demanding during the civil war, and yet it is necessary. Therefore, no matter how the challenges arise, educating young people to have to be continued by creating a possible environment.

\section{Implementation of the strategies during the civil war}

To be an effective teacher, creative and innovative strategies are required to meet the needs of students. According to Amado (2015), teachers' instruction and approaches are essential because they create to reach a desirable teaching-learning environment. In this context, the teacher stated,

"In my current situation, wherever I went (there were times when I had to flee for CDM and sometimes when I had to flee the war), I kept in touch with as many children as possible." 
And another teacher mentioned,

"Since children are wandering around, I decided to teach them with the advice of the parents."

And another teacher put it,

"To help and to teach children, I go the houses of children and also go the monastery where families are sheltering as a camp.”

And another teacher revealed,

"By this time, warm welcoming to each student is the best medicine to heal fear and belongingness. So I am not tired of addressing a smile on my face. I speak in a friendly manner and teach creatively. From time to time, I did funny things to make children happy and forget about the war.”

"In my online teaching, I use not only textbooks but also educational videos, articles that are found on the website to enhance their knowledge and at the same time, it calls their interest."

And another teacher said,

"Courageously, I inform the neediest families in the face of anxiety and fear. It has to be opened in consultation. Parents are actively involved, and I form small groups like the tutorial style so that each child can learn well and military will not run after me."

It can be seen that the respondents have their way of teaching; some go from one house to the other, some by their presence, giving a smile and encouraging words, and giving their time to listen to the other. Somehow, the strategies of the teachers are related to the psychomotor skill of children. According to Martínez-Moreno et al. (2020) motioned that childhood psychomotor skills to begin with getting to know each child and being able to analyze in order to create the best tools for the children. Aside from the textbook, the instructor utilized indoor and outdoor activities, home visits, evaluating teaching and learning outcomes. Furthermore, some teachers are looking for more attractive educational materials to be able to divert their students from what is going on in the country but at the same time instructing them. 


\section{The effect of the new teaching strategies during the civil war}

Teachers' practices are essential for understanding and developing learning processes. Practical approaches and practices can create effective learning by meeting the needs of individual students. In this context, the teacher claimed,

"During the military coup, our education was beneficial to the children. It helps a lot for children who are far away from education. We did our best to teach children who did not get a basic education in government schools. Children now enjoy learning and are interested in education. They were taught under fear, but when they taught with a view to their children's future, they did not know what the threats, barriers, and obstacles were. I dare to face adversity."

And another teacher observed,

"Since I use creativity in my approaches, it gives happiness to the students they learn to do things creatively. It promotes good manners."

And another teacher claimed,

"It strengthens the spirit and relieves fear."

And another teacher stated,

"I am happy because children become smarter. Our teaching approaches can heal trauma. Their education has improved, and their relationships have improved.

It can be seen that the sacrifices of the respondents are bearing fruit little by little. By giving a safer environment to the students, there is much learning going on, maybe more than they are expecting. Even though there is no proper place to gather the students, they learn to adopt new strategies for teaching, looking at the country's current situation and students.

\section{Discussion}

Implementation of the strategies in early childhood education was evaluated in this study, and a number of outcomes were found. Despite the current insecure environment, troops deployed at schools and various burnings, bombings kind of terrorist's acts, spreading of covid-19, various 
families' strikes against the military junta who did not register their children under the education system of the military junta, which consequently delay the learning of each child in Myanmar, teacher take courage and risk by utilizing the new way of approaches to ensure students learn from home or at the village and town where he or she lives. Early childhood education is the foundation of education. Therefore, the child has to be well taught and develop the necessary skills in this stage. To respond to each child's education in Myanmar, the educators structure home-based learning lessons to be able to reach out to children. The curriculum is available in shareable, and the lesson will be learned sufficiently by students' concentration of 1 to 3 hours per day, expecting that frequently studying them will lead to expertise.

In the moment of civil war, teachers take their profession as a mission, no matter how challenging the situation and even it demands a lot of sacrifice and effort, they learn how to be innovative, creative, and present to the students. Since the children are affected mentally, emotionally, and spiritually during the civil war, ECE's pupils need the teacher's effort more than ever before. A good teacher always finds ways what is good for their student, and if the strategies are not effective, they are courageous enough to find more compelling. In a state of war, formal education is very hard to do. All the respondents' strategies are the helping tools for learning. ECE's pupils have the opportunity to continue education for their development and are healed from the trauma caused by civil war. At the same time, considering that the students learn more when they feel that the environment is safe and that the people around them are not threatening, the teachers are trying their ways to provide it simply. Moreover, It is true that learning also happens regardless of the place because sometimes they do the classes even under the tree or under the bridge, yet the atmosphere breathes a sense of joy and camaraderie, and surely learning would take place. However, in the case of a civil war, the atmosphere itself is threatening.

Besides, the methodologies of somehow personal approach, teaching the small number of students, of going from one house to the other, and being present to the students are an effective way for them to learn. This situation develops trust in both the teacher and the student, which would somehow create a good relationship with the student and their family. Although this new way is more demanding because it breaks the tradition that the teacher is waiting for the students in the classroom then after the class, the student will go back to their own family, now, it is the teacher 
who will look for their students, and the classroom will be in the family. Nevertheless, the reality of civil war is leading to this new way, and it has good and bad effects; however, to respond to the need for education, especially to the young, this method is effective.

The strategies implemented during the civil war may not be aligned with the policy issued by the education ministry of Myanmar, yet it still gives meaning to the lives of children. There are many challenges for the teacher to innovate approaches that can cause their lives. Though teachers cannot create fixed strategies or approaches due to the emergency issue, teaching individuals' space and time is an effective way to reach and teach children.

\section{Conclusion}

Myanmar education is ceased due to the civil war. However, the new approaches and strategies which the teachers implement in early childhood educations during the civil war are the best antidote for this crucial moment. The practices have developed intellectual and spiritual aspects that can heal the children's wounds and give hope. The manner of applying teaching strategies for early childhood education always depends on the availability of facilities, spaces, and situations of given lifestyles. Home-based learning ensures a comfortable learning and self-study environment for students under the guidance of parents, teachers from town, and other elderlies and youths. In the meantime, home-based learning is mainly created to prioritize upgrading the students' innovative capabilities and learning each child in their own space. However, it is not appropriate for the long term because children are social human beings who need to connect with other children for interaction, which will allow them to progress in a good relationship. When schools can reopen for in-person classes, the early childhood education system should not be counted on by-heart learning but should establish an easy and genuine education system. 
References:

1. Amado , R. C. (2015, November 3). Methods and teaching strategies used by teacher ... APJMR. Retrieved December 16, 2021, from http://www.apjmr.com/wpcontent/uploads/2016/04/APJMR-2015-3.5.3.05.pdf

2. Cherrie, P. (2018, May 23). What is early childhood education? 7 things to know about the field forming future generations. The Wheelock Blog. Retrieved December 16, 2021, from https://blog.wheelock.edu/what-is-early-childhood-education/

3. The department of the Education in Queenland. (2020, September 30). Policy and procedure guidance. Early Childhood Education and Care. Retrieved December 16, 2021, from https://earlychildhood.qld.gov.au/legislation-and-guidelines/policy-and-procedure-guidance

4. Franks, R. P., Pecoraro, M., Singer, J., Swenson, S., \& Wilson, J. B. (2017). Early childhood development: Implications for policy ... Retrieved December 16, 2021, from https://jbcc.harvard.edu/sites/default/files/jbcc_early_childhood_policy_brief_2017.pdf

5. Gersovitz, M., \& Kriger, N. (2013, August 1). What is a Civil War? Acritical review of its definition and (econometric) consequences. Open Knowledge Repository. Retrieved December 16, 2021, from https://openknowledge.worldbank.org/handle/10986/21428?show=full

6. Heiduk, F. (2021, May 29). Civil War in Myanmar. A further escalation of violence looms on the Horizon. Policy Commons. Retrieved December 16, 2021, from https://policycommons.net/artifacts/1535879/civil-war-in-myanmar/2225773/

7. Kapur, R. (2018). Early Childhood Education . https://doi.org/https://www.researchgate.net/publication/323961021_Early_Childhood_Educa tion -

8. Martínez-Moreno, A., Imbernón Giménez, S., \& Díaz Suárez, A. (2020). The psychomotor profile of pupils in early childhood education. Sustainability, 12(6), 2564. https://doi.org/10.3390/su12062564

9. Myant , O. K. (2014). Myanmar policy for Early Childhood Care and Development. Retrieved December 16, 2021, from https://www.unicef.org/myanmar/media/2876/file/Policy\%20for\%20ECCD\%20$\% 20$ English\%20Version.pdf 